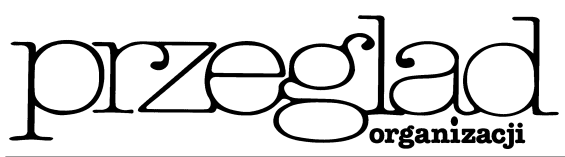

\title{
Procesy organizacyjnego uczenia się w aliansie strategicznym
}

https://doi.org/10.33141/po.2005.05.02

Bogusz Mikuła
Przegląd Organizacji, Nr 5 (784), 2005, ss. 9-12 www.przegladorganizacji.pl Towarzystwo Naukowe Organizacji i Kierownictwa (TNOiK)

\section{Istota i cele aliansów strategicznych}

W początkowej fazie istnienia koncepcji zarządzania strategicznego strategię konkurencji przedsiębiorstwa rozumiano jako kompleks działań zaczepno-obronnych przed pięcioma siłami konkurencji. Określano teren walki oraz środki pozwalające zdobyć klienta i zdominować obrany segment rynku. Jednak wraz ze wzrostem dynamiki zmian w otoczeniu, szybkim rozwojem techniki, technologii, wzrostem konkurencji, nasileniem się zmian politycznych, społecznych i ekonomicznych powodujących, że punktem odniesienia dla działalności przedsiębiorstw stał się cały świat, owa filozofia walki z konkurencją zdezaktualizowała się. Okazało się, że przedsiębiorstwa w pojedynkę nie zdołają sukcesywnie rozwijać się i utrzymać swojej pozycji konkurencyjnej. Nastąpiło więc ewolucyjne otwarcie się przedsiębiorstw na wzajemną współpracę prowadzącą do minimalizowania ryzyka, lepszego wykorzystania zasobów i szybszego rozwoju. Stopniowo coraz szersze wykorzystanie znajdują alianse strategiczne, a obecnie jest to jedna ze szczególnych metod tworzenia organizacji sieciowych.

Alians strategiczny definiowany jest jako współpraca między aktualnymi lub potencjalnymi konkurentami mająca wpływ na sytuację innych konkurentów, dostawców lub klientów w obrębie tego samego lub pokrewnych sektorów. Tego rodzaju przymierze charakteryzują specyficzne stosunki między jego uczestnikami, w wyniku których rywalizacja nie ustaje, ale jest ona świadomie ograniczana w określonym czasie i obszarze działalności [Romanowska 2002, s. 163].

Wśród zasadniczych celów tworzenia aliansów strategicznych wymienić można:

- wzajemną kooperację pozwalająca minimalizować koszty (np. transakcyjne, a przez to całkowite), optymalizować jakość, lepiej zaspokajać potrzeby klientów,

- wejście na nową pozycję i nawiązanie relacji z innymi firmami,

- pozyskanie nowych klientów,

- opanowanie kontaktów handlowych nad grupa klientów, a w ten sposób wzmocnienie swojej siły przetargowej wobec nich,

- neutralizowanie potencjalnego konkurenta,

- pozyskiwanie szerszego zakresu informacji,

- uzupełnienie kompetencji (np. poprzez wymianę umiejętności technicznych i zarządczych) oraz lepsze wykorzystanie zasobów niematerialnych i materialnych,
- wykorzystanie zasobów partnera (np. sieci dystrybucji),

- skrócenie cyklu opracowania koncepcji produktu lub usługi,

- osiagnięcie dużych rozmiarów działalności i zmniejszenie ryzyka w innowacyjnych przedsięwzięciach,

- zwiększenie prawdopodobieństwa udanego wprowadzenia innowacyjnego produktu na rynek,

- krytyczne podejście do niepożądanych zachowań partnerów, wymiana i wspólne podzielanie właściwych z punktu celów współpracy norm i wartości, a więc tworzenia wspólnej proefektywnościowej kultury organizacyjnej,

- wspólne uczenie się, wymiana i rozwój wiedzy,

- zwiększenie elastyczności działania (por.: [Doz, Hamel 1998, s. 4-5], [Brilman 2002, s. 433-440]).

Pogłębianie się obecnie świadomości przedsiębiorstw działania w warunkach gospodarki opartej na wiedzy powoduje, że coraz częściej zasadniczym celem podejmowania aliansu strategicznego staje się chęć rozszerzenia swojej wiedzy o wiedzę partnera lub też zjednoczone uczenie się i tworzenie nowej wiedzy, a następnie wspólne jej wykorzystanie. Proces transferu i tworzenia wiedzy między partnerami aliansu strategicznego prowadzony może być różnymi metodami. Kształt tego procesu w dużej mierze uzależniony jest od przyjętej przez przedsiębiorstwa partnerskie koncepcji zarządzania wiedzą (sposobu ujęcia wiedzy i wyróżnianych jej rodzajów, modelu procesu generowania wiedzy, podejścia $\mathrm{w}$ budowie systemu zarządzania wiedzą itp.). Przykładem procesu transferu, wspólnego rozwoju i wykorzystania wiedzy przez firmy partnerskie są etapy działania podane przez M. Weissenberger-Eibl kolejno obejmujące: identyfikację wiedzy, transfer i modyfikację, zastosowanie, administrowanie wiedzą, kontrolę (szerzej: [Mikuła, Pietruszka 2001, s. 322-324]). W dalszej części omówiono procesy generowania wiedzy $\mathrm{w}$ aliansie strategicznym oparte na koncepcji procesów organizacyjnego uczenia się.

\section{Podstawowe elementy procesu organizacyjnego uczenia się}

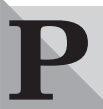
roces organizacyjnego uczenia się wiąże się z działaniami adaptacyjnymi, tworzeniem i wdrażaniem koncepcji działania, zmianą zachowań organizacyjnych, ale przede wszystkim z wiedzą i umiejętnościami, ich pozyskiwaniem, transferem, rozwojem i wykorzystaniem. Analiza teorii uczenia się ludzi i organizacji prowadzi do przekona- 
nia, że organizacja będzie się uczyć, jeśli pojawi się co najmniej jeden $\mathrm{z}$ poniższych warunków:

- wystapi trwała zmiana w sposobie działania organizacji;

- wystapi zmiana nietrwała, ale zawierająca nowe, dotąd nie stosowane elementy;

- nastąpi zmiana w ilości posiadanych przez organizację informacji lub w ich strukturze, bądź też zmiana w ilości lub też jakości posiadanej wiedzy.

Na organizacyjne uczenie się patrzeć też można w przekroju jego trzech składowych subprocesów: tradycyjnego, empirycznego i cybernetycznego uczenia się.

Tradycyjne (inaczej edukacyjne) uczenie się, to proces doskonalenia kompetencji ludzi poprzez ich aktywny udział w różnego rodzaju formach szkolenia i doskonalenia zawodowego organizowanych w miejscu pracy lub poza nim. Tradycyjne uczenie się również może mieć postać nieformalnego mentoringu czy udziału we wspólnotach praktyków.

Bardzo istotnym składnikiem organizacyjnego uczenia się jest uczenie się przez praktyczne działanie. Oczywiście nauka przez praktykę będzie pełna tylko wówczas, gdy wcześniej poprzedzona zostanie dostarczeniem pracownikowi odpowiedniej wiedzy teoretycznej podczas edukacyjnego uczenia się. To praktyczne działanie stanowi istotę empirycznego uczenia się. W trakcie niego ludzie zdobywają nowe doświadczenia, które w procesie myślowym człowieka przetwarzane są następnie w wiedzę, a gdy proces empirycznego uczenia się zachodzi zespołowo, to w ramach niego dokonuje się również transfer wiedzy między współpracownikami.

Aby proces uczenia się organizacji był pełny, realizowane musi być także cybernetyczne uczenie się. Polega ono na odkrywaniu nowych sposobów widzenia i rozumienia norm, reguł, zasad, standardów rządzących funkcjonowaniem organizacji, ich kwestionowaniu i zmianie. Innymi słowy jest to proces odrzucania starych nawyków i sposobów myślenia ludzi, które warunkują ich zachowanie. Pracownicy kolektywnie doskonalą zasady regulujące postępowanie w organizacji, sposoby widzenia i rozumienia tych zasad, kwestionują misję i strategię organizacji poprzez tworzenie wspólnej wizji jej przyszłości. Cybernetyczne uczenie się przebiega najczęściej podczas rozwiązywania problemów. Ważnym aspektem tego subprocesu organizacyjnego uczenia się jest koncentracja, nie tyl-

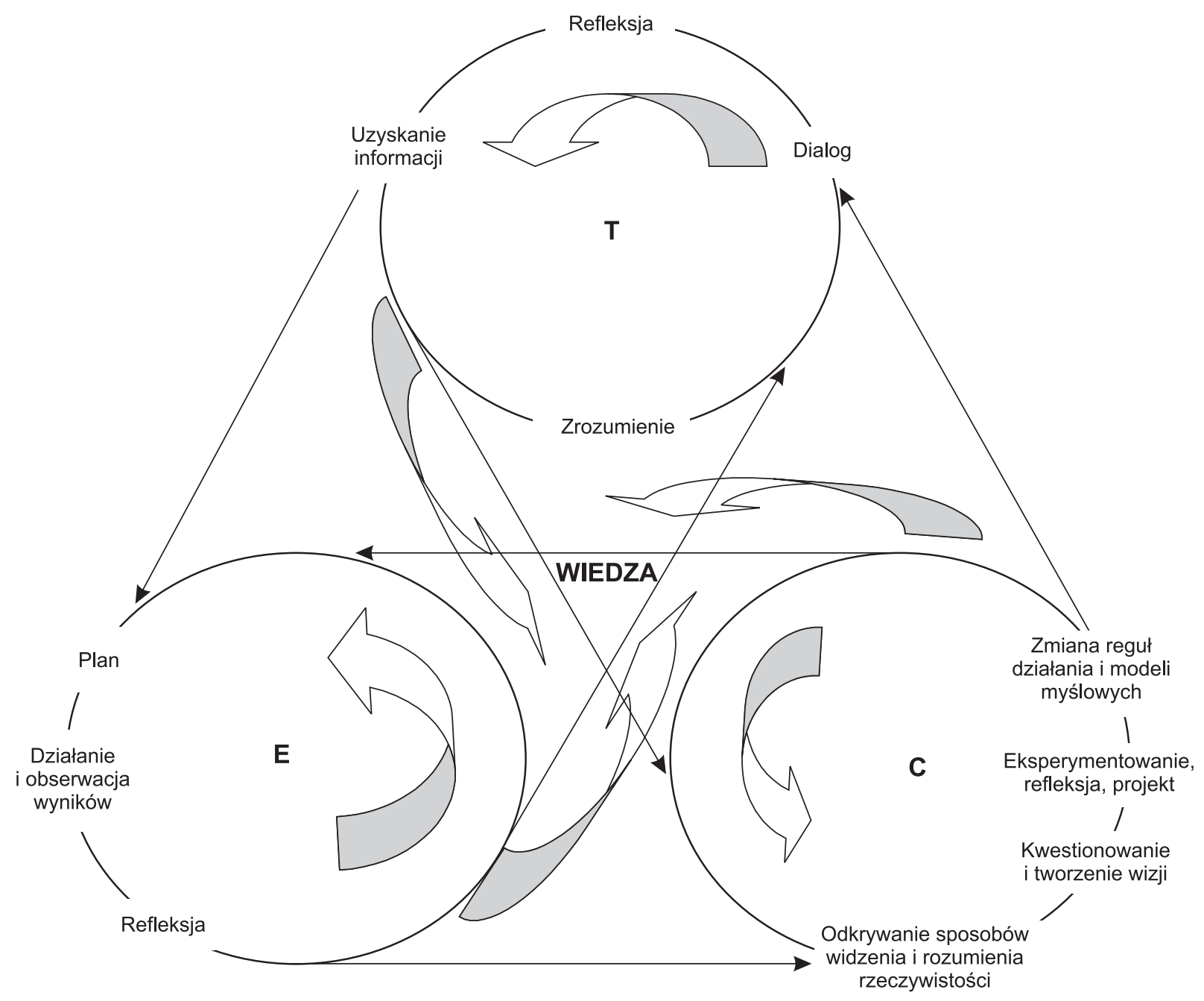

Rys. 1. Model tworzenia i transferu wiedzy oparty na procesach organizacyjnego uczenia się (TEC) Źródło: opracowanie własne. 
ko na regułach czy zasadach dotyczących obszaru strategicznego i operacyjnego, ale także sposobach uczenia się organizacji, ich modyfikacji i doskonalenia.

Każdy z subprocesów organizacyjnego uczenia się przedstawić można za pomocą pętli. Model zaprezentowany na rys. 1 (zastosowane litery T, E, C sa pierwszymi literami nazw poszczególnych subprocesów organizacyjnego uczenia się) pokazuje, że wiedza wytworzona w efekcie cybernetycznego uczenia się stosowana jest następnie podczas empirycznego uczenia się, dzięki czemu wykonawcy praktyk są w stanie osiągnąć jej głębsze rozumienie. Podstawowymi sposobami rozprowadzania wiedzy zdobytej podczas empirycznego i cybernetycznego uczenia się są metody stosowane podczas edukacyjnego uczenia się.

\section{Procesy organizacyjnego uczenia się partnerów poprzez alians strategiczny}

$\mathbf{T}$

eoria uczenia się organizacji skupia głównie uwagę na procesach zachodzacych wewnątrz organizacji, ale coraz częściej rozpatruje się te procesy jako czynnik wiążący organizacje partnerskie, pozwalający wspólnie pozyskiwać wiedzę, rozwijać ją i wykorzystywać. R.J. Mockler [2000, s. 136] uznaje uczenie się partnerów z podjętego aliansu strategicznego jako jedno z czterech zasadniczych kryteriów pomiaru jego sukcesu.

Zastosowanie procesów organizacyjnego uczenia się partnerów poprzez alians zależy od przyjętych celów i typu aliansu. Jeśli cele te uwzględniają wspólne uczenie się i wykorzystanie wiedzy (w określonym obszarze działania), procesy organizacyjnego uczenia się integrują partnerów poprzez: tworzenie lub identyfikowanie przez nich nowej wiedzy, transferowanie i interpretowanie wiedzy, wykorzystanie wiedzy do realizacji działań umożliwiających osiąganie zamierzonych wyników [Dolińska 2005, s. 22].

Zakres wykorzystania poszczególnych subprocesów organizacyjnego uczenia się w aliansie strategicznym zależy od obszaru współpracy oraz wielu specyficznych uwarunkować wewnętrznych i zewnętrznych. Nie zawsze wspólne uczenie się musi prowadzić do wytworzenia wiedzy dotąd nie istniejącej, co jest najczęściej

Tab. Niektóre narzędzia realizacji subprocesów organizacyjnego uczenia się w ramach aliansu strategicznego

\begin{tabular}{|c|l|}
\hline $\begin{array}{c}\text { Subprocesy organizacyjnego } \\
\text { uczenia się }\end{array}$ & \multicolumn{1}{|c|}{$\begin{array}{c}\text { Metody realizacji procesów organizacyjnego uczenia się } \\
\text { w aliansie strategicznym }\end{array}$} \\
\hline Tradycyjne uczenie się & $\begin{array}{l}\text { samokształcenie, szkolenia i treningi, udział w sympozjach i konferencjach, } \\
\text { e-learning, data warehousing, business intelligence, wspólnoty uczenia się, inter- } \\
\text { net, intranet, ekstranet, groupware, coaching, mentoring (również nieformalny) } \\
\text { i inne }\end{array}$ \\
\hline Empiryczne uczenie się & $\begin{array}{l}\text { praktyczne działanie, rotacja personelu, instruktaż, ćwiczenie dialogu, analiza } \\
\text { trendów rozwojowych zjawisk, uczenie się na błędach, panele z klientami i do- } \\
\text { stawcami, benchmarking, wdrażanie nowych rozwiązań do praktyki, eksperymen- } \\
\text { towanie z nowymi metodami, analiza reklamacji, partycypacja w zarządzaniu, } \\
\text { tworzenie aktywnego otoczenia sprzyjającego nauce i inne }\end{array}$ \\
\hline Cybernetyczne uczenie się & $\begin{array}{l}\text { przegląd sytuacji kryzysowych i niebezpiecznych, audyty, kwestionowanie wszel- } \\
\text { kich założen, norm, metod działania (w tym sposobów organizacyjnego uczenia } \\
\text { się), zespoły projektowe, koła jakości, kaizen, wspólnoty twórcze (ekspertów), } \\
\text { groupware, metody heurystyczne, tworzenie innowacji, tworzenie nowych stan- } \\
\text { dardów wykonania i inne }\end{array}$ \\
\hline
\end{tabular}

Źródło: opracowanie własne.

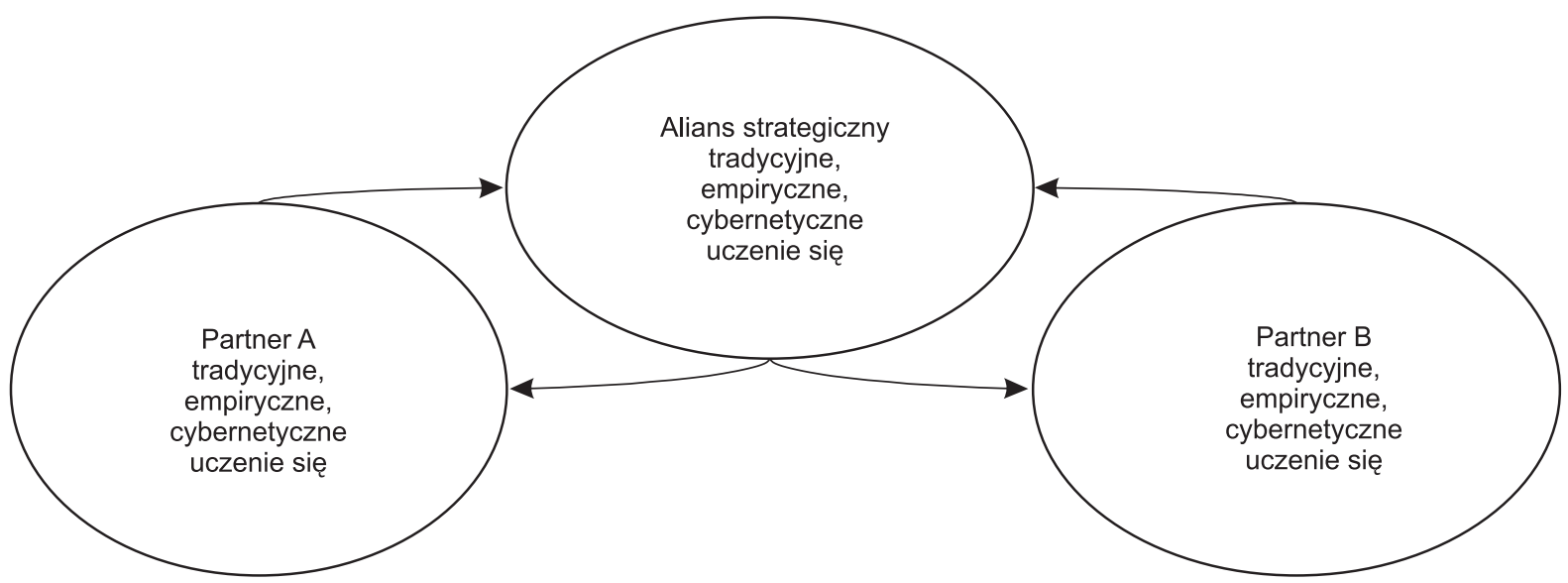

Rys. 2. Uczenie się w aliansie i indywidualne uczenie się partnerów

Źródło: opracowanie własne. 
bardzo kosztowne. Przykładowo, jeśli alians koncentruje się na obszarze wiedzy o produkcie to zakres wykorzystania poszczególnych subprocesów organizacyjnego uczenia się zależy między innymi od: poziomu dojrzałości produktu, stopnia jego uklientowienia, dominującego typu wiedzy stosowanego do rozwiązywania problemów (jawnej lub ukrytej), poziomu dojrzałości i stabilności przemysłu. Ogólnie rzecz biorąc, jeśli produkt partnerów jest dojrzały, powinni się oni koncentrować na wymianie posiadanej wiedzy i jej oczyszczeniu poprzez wykorzystanie sposobów tradycyjnego i empirycznego uczenia się, wspomagając się wybranymi sposobami cybernetycznego uczenia się. Gdy jednak produkt partnerów jest w fazie rozwoju, szersze wykorzystanie powinny zyskać wspólnie realizowane procesy cybernetycznego uczenia się. Koncentracja na cybernetycznym uczeniu się musi też dominować, gdy produkt ma wysoki poziom uklientowienia, ale gdy jest standardowy, wówczas wystarczające może okazać się stosowanie tradycyjnego lub/i empirycznego uczenia się. W sytuacji wykorzystywania podczas rozwiązywania problemów głównie wiedzy jawnej zastosowanie powinny znaleźć te sposoby organizacyjnego uczenia się, które polegają na przekazywaniu informacji (niekoniecznie twarzą w twarz). Spersonalizowane sposoby wspólnego uczenia się powinny być zastosowane w sytuacji dominującego wykorzystania wiedzy cichej podczas rozwiązywania problemów. Jeżeli przemysł, w jakim działają partnerzy, jest stabilny i dojrzały, w większym zakresie wykorzystanie powinny znaleźć metody tradycyjnego i empirycznego uczenia się. Jeśli przemysł jest w fazie dynamicznego rozwoju lub jego stabilność jest zagrożona substytutami, szeroko użyte powinno zostać cybernetyczne uczenie się.

W praktyce aliansu strategicznego generowanie i użycie wiedzy oparte na koncepcji procesów organizacyjnego uczenia się polega na wspólnym wykorzystaniu dobranych $\mathrm{w}$ zależności od potrzeb i sytuacji narzędzi tradycyjnego, empirycznego lub/i cybernetycznego uczenia się (wybrane podano w tabeli i zaznaczyć należy, że niektóre z nich pełnią bardziej złożone funkcje w stosunku do poszczególnych subprocesów - por.: [Dolińska 2005, s. 21]; [Finger, Bürgin Brand 1999, s. 148]; [Mikuła 2000, s. 24]). Całość prowadzonych działań powinna być zorganizowana i sterowana przez jednego $\mathrm{z}$ aliantów lub też specjalnie powołany zespół, tzw. brokera. Między innymi określa on obszar wiedzy i zakres organizacyjnego uczenia się oraz sposoby jego realizacji w aliansie, sposoby przepływów wiedzy z aliansu do organizacji partnerskich, metody protekcji wiedzy chronionej aliantów oraz oceny efektów organizacyjnego uczenia się, wyznacza i tworzy potrzebne relacje, administruje infrastrukturą (bazami danych) i zarządza środkami finansowymi przeznaczonymi na organizacyjne uczenie się w aliansie. Nie oznacza to jednak, że partnerzy rezygnują z indywidualnego uczenia się realizowanego w swoim wnętrzu. Wręcz przeciwnie, każdy z nich nadal jest zobowiązany w sposób ciagły uczyć się na podstawie doświadczeń własnych i innych (też spoza aliansu), przyczyniając się w ten sposób do rozwoju powodzenia partnerstwa (zależność tę obrazuje rys. 2).

\section{Podsumowanie}

$\mathbf{R}$ ealizacja procesu organizacyjnego uczenia się prowadzić powinna w konsekwencji do zmian w zachowaniach ludzi i tym samym organizacji partnerskich. Jednak jak dalekie i jak innowacyjne będą to zmiany, uzależnione jest to od rodzaju i siły orientacji w procesie uczenia się organizacji, która może przyjąć postać:

- reaktywnej - charakteryzującej się ostrożnością i naśladowaniem innych organizacji,

- proaktywnej - cechującej się ryzykiem, wysokim poziomem innowacyjności i ciągłością zmian (szerzej zob.: [Mikuła 2004, s. 51-59]).

Dodatkowo efektywność uczenia się w aliansie strategicznym uzależniona jest między innymi od posiadanych przez partnerów umiejętności realizacji procesów organizacyjnego uczenia się i zarządzania nimi [Dolińska 2005, s. 22] oraz wielu czynników określanych jako kontekst zarządzania wiedzą. W skład kontekstu wchodzą czynniki otoczenia aliansu strategicznego (czynniki otoczenia podmiotowego i makrootoczenia), jak i wewnętrzne uwarunkowania poszczególnych partnerów (struktury organizacyjne, kultury organizacyjne, klimaty organizacyjne panujące we współpracujaccych zespołach pracowniczych partnerów, budowa systemów zarządzania wiedzą partnerów, systemy motywacji, struktury zatrudnienia, poziom posiadanej wiedzy, stosowane technologie itp.) (szerzej zob.: [Mikuła 2003, s. 33-47]).

dr Bogusz Mikuta

Katedra Zachowań Organizacyjnych Akademii Ekonomicznej w Krakowie

BIBLIOGRAFIA

[1] BRILMAN J., Nowoczesne koncepcje i metody zarzadzania, PWE, Warszawa 2002.

[2] DOLIŃSKA M.,Procesy uczenia się w organizacji i aliansie strategicznym, „Przeglą Organizacji” 2005, nr 1.

[3] DOZ Y. L., HAMEL G., Alliance Advantage. The Art of Creating Value through Partnering, Harvard Business School Press, Boston, Massachusetts 1998.

[4] FINGER M., BÜRGIN BRAND S.B., The Concept of the "Learning Organization" Applied to the Transformation of the Public Sector, [w:] Organizational Learning and Learning Organization. Developments in Theory and Practice, red. M. EASTERBY-SMITH, L. ARAUJO, J. BURGOYNE, Sage Publications, London 1999.

[5] MIKUŁA B., Pojęcia, aspekty, system i kontekst zarzadzania wiedza, [w:] Zarzadzanie wiedza $i$ informacja $w$ spoteczeństwie sieciowym, Tom I, praca zbiorowa pod red. M. MORAWSKIEGO, „Prace Wałbrzyskiej Wyższej Szkoły Zarządzania i Przedsiębiorczości”, seria „Zarządzanie i Marketing", Wałbrzych 2003.

[6] MIKUŁA B., Procesy organizacyjnego uczenia, „Przegląd Organizacji” 2000, nr 12.

[7] MIKUŁA B., Wykorzystanie procesów organizacyjnego uczenia się w generowaniu wiedzy, „Q Jakości” 2004, nr 1. [8] MIKUŁA B., PIETRUSZKA A., Zarzadzanie wiedza a sieci aliansów strategicznych, [w:] Zarzadzanie strategiczne. Stan i perspektywy rozwoju, praca zbiorowa pod red. R. KRUPSKIEGO, Komitet Nauk Organizacji i Zarzadzania Polskiej Akademii Nauk, Wałbrzyska Wyższa Szkoła Zarządzania i Przedsiębiorczości, Wałbrzych 2001.

[9] MOCKLER R. J., Multinational Strategic Alliances, Wiley, Chichester 2000.

[10] ROMANOWSKA M.,Alianse strategiczne w świetle koncepcji zasobowej, [w:] Przedsiębiorstwo partnerskie, praca zbiorowa pod red. M. ROMANOWSKIEJ, M. TROCKIEGO, Difin, Warszawa 2002. 